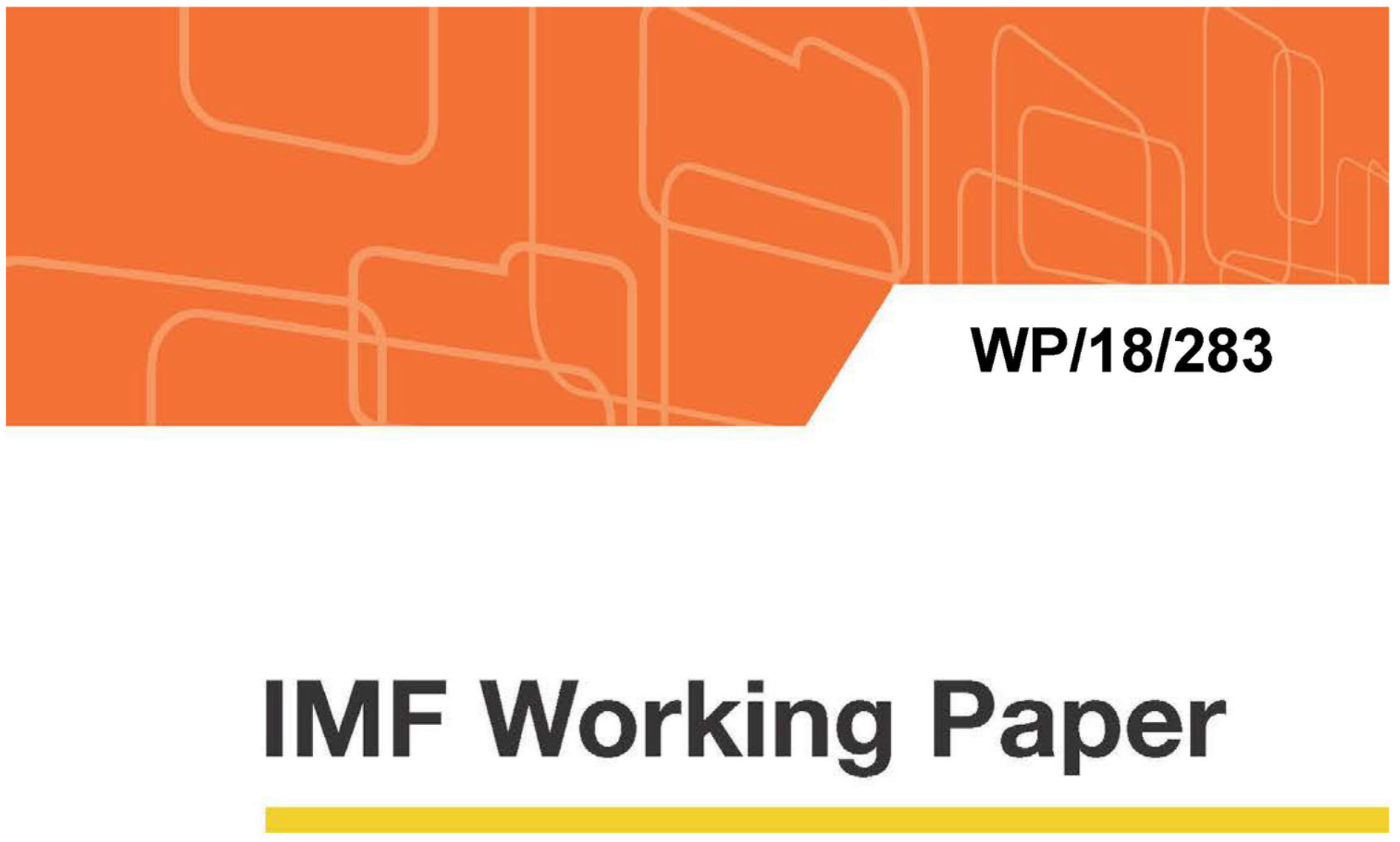

\title{
Drivers of Spain's Export Performance and the Role of Labor Market Reforms
}

by Jorge Salas

IMF Working Papers describe research in progress by the author(s) and are published to elicit comments and to encourage debate. The views expressed in IMF Working Papers are those of the author(s) and do not necessarily represent the views of the IMF, its Executive Board, or IMF management. 


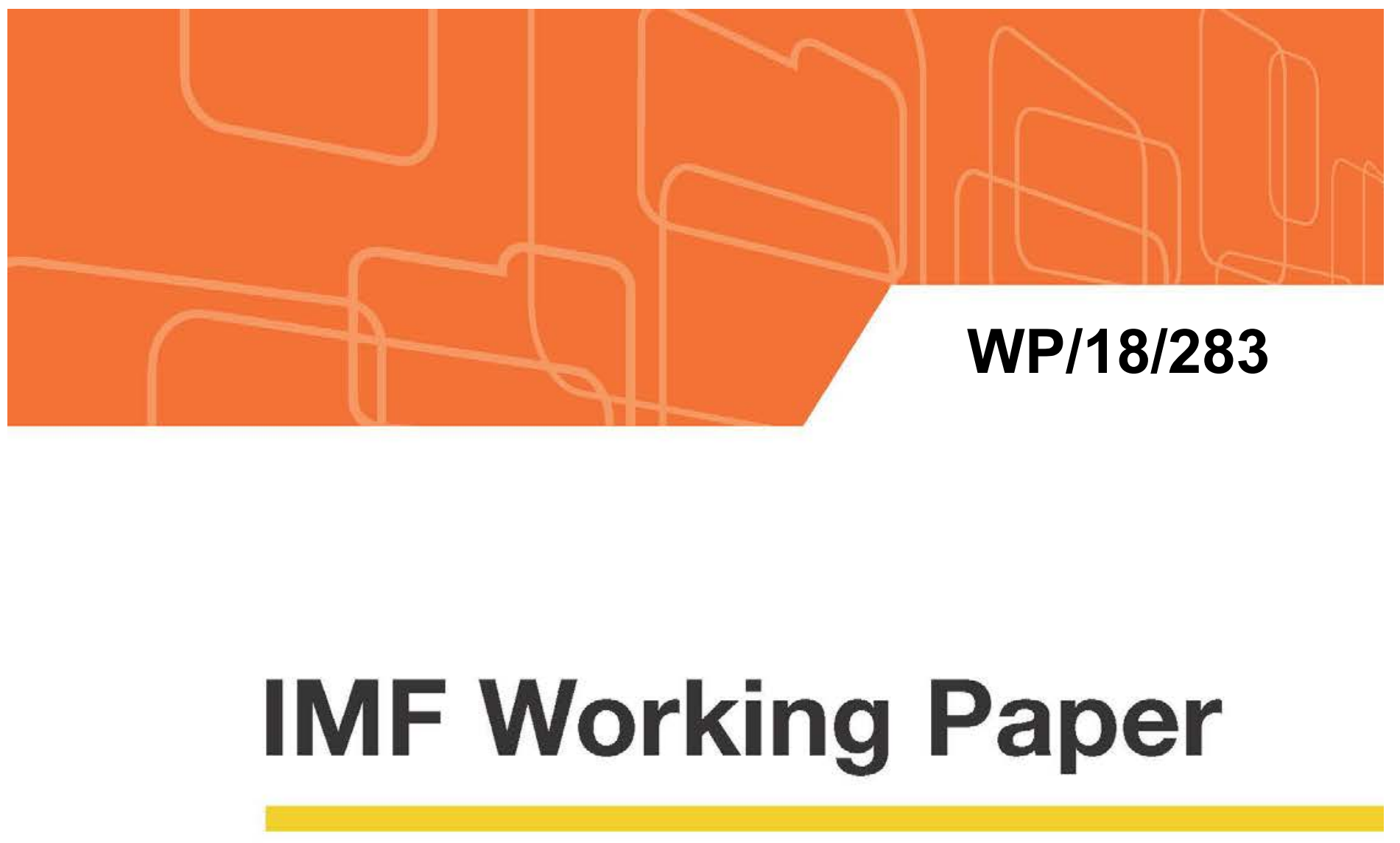

\section{Drivers of Spain's Export Performance and the Role of Labor Market Reforms}

by Jorge Salas

IMF Working Papers describe research in progress by the author(s) and are published to elicit comments and to encourage debate. The views expressed in IMF Working Papers are those of the author(s) and do not necessarily represent the views of the IMF, its Executive Board, or IMF management.

$$
\text { I N T E R N A T I O N A L M O N E T A R Y F U N D }
$$




\title{
IMF Working Paper
}

European Department

\section{Drivers of Spain's Export Performance and the Role of Labor Market Reforms ${ }^{1}$ Prepared by Jorge Salas}

Authorized for distribution by Andrea Schaechter

December 2018

\section{IMF Working Papers describe research in progress by the author(s) and are published to elicit comments and to encourage debate. The views expressed in IMF Working Papers are those of the author(s) and do not necessarily represent the views of the IMF, its Executive Board, or IMF management.}

\begin{abstract}
Spain's export performance strengthened after the global financial crisis, and exports now represent more than a third of GDP. This paper argues that several factors contributed to that achievement: external demand, supported by greater diversification of destination markets; enhanced export orientation of Spanish firms, partly as a response to lower domestic demand after the crisis; and competitiveness gains, reflecting in part changes in the labor market following structural reforms adopted in 2010 and 2012. Based on crosscountry panel regressions linking real export growth to employment protection indicators, those labor market reforms are estimated to account for nearly one-tenth to above onequarter of Spain's total export growth rate from 2010 to 2013.
\end{abstract}

JEL Classification Numbers: F1, F14, F16

Keywords: Export Growth, Competitiveness, Labor Market Reforms, Employment Protection, Spain, Advanced Economies

Author's E-Mail Address: JSalas@imf.org

\footnotetext{
${ }^{1}$ Tingyun Chen provided excellent research assistance. The author is grateful to participants of a seminar hosted by the Bank of Spain for their useful comments and suggestions.
} 
Abstract

I. Introduction $\underline{3}$

II. Recent Evolution of Spanish Exports: A Brief Description $\underline{4}$

III. Assessing the Drivers of Export Growth 1

IV. A Closer Look at the Role of Labor Market Reforms: Impact of Employment Protection on Exports in a Cross-Country Framework

V. Conclusions $\underline{16}$

References $\underline{18}$

Box

Counterfactual: Competitiveness and Exports with more Flexible Wages Since 2008 10

\section{Tables}

1. Standard Determinants of Exports $\underline{8}$

2. Effects of Employment Protection on Export Growth $\underline{14}$

\section{Appendix}

Further Details and Results Related to the Cross-Country Panel Regressions 


\section{INTRODUCTION}

Spain's export performance strengthened in the aftermath of the global financial crisis. Exports of goods and services have increased from 26 percent of GDP in 2007 to 34 percent of GDP in 2017. This is a notable achievement for a country that, from a longer perspective, has taken advantage of the benefits from trade integration, especially since its accession to the European Union in 1986 (Myro, 2015). In the post-crisis years, Spain has also increased its share of world goods exports at a faster pace than other EU countries, such as Germany and Italy.

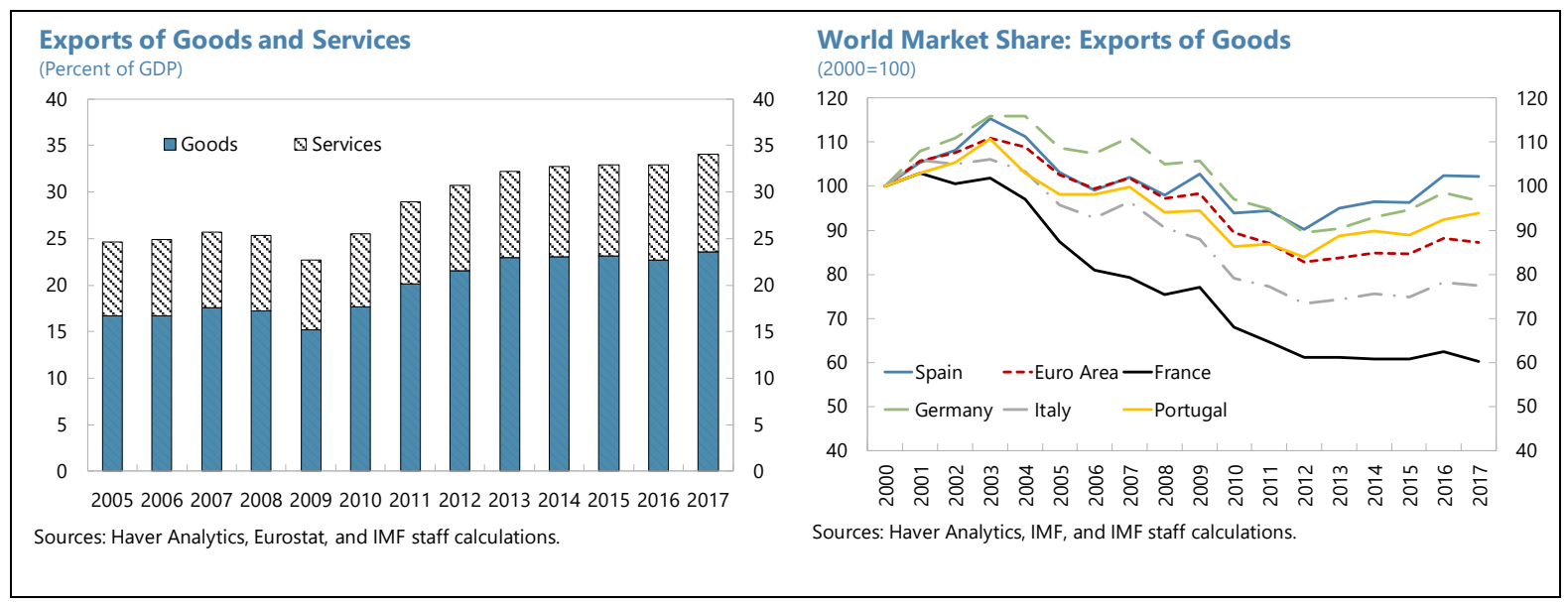

The increase in exports has helped to achieve current account surpluses

since 2013. Associated with the expansion of exports, the current account has improved from a deficit of 10 percent of GDP in 2007 to an average surplus of around 1.5 percent of GDP in 2013-17. The reversal of the current account position is a welcome development for Spain. Sustaining this performance will be important to reduce its large negative net international investment position (-84 percent of GDP at end-2017) over the

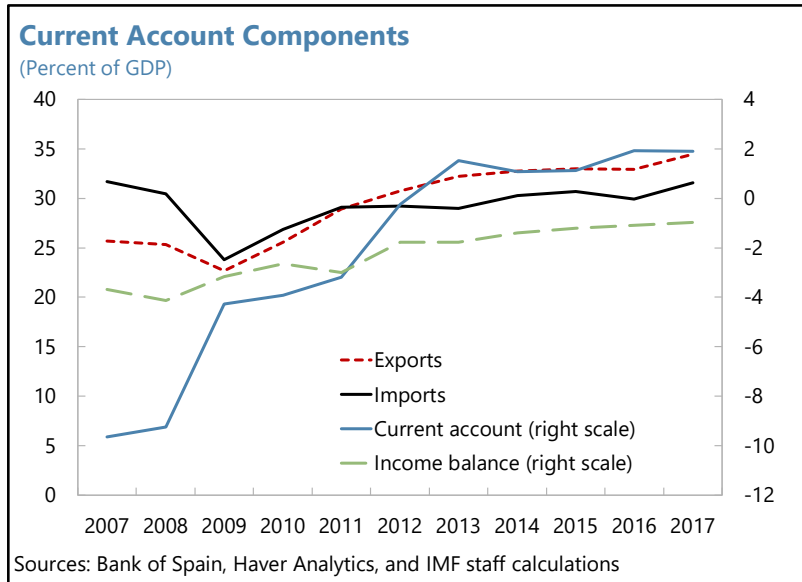
medium term.

\section{This paper sheds light on the drivers of Spain's strong export growth until 2017. A} regression analysis shows that external demand considerably helped to boost exports, partly reflecting gains from increased geographic diversification, and that the contribution of competitiveness to export growth became positive after the crisis. Simple counterfactual exercises, based on econometric results from the OECD (2014) and Doménech et al. (forthcoming), suggest that the labor market reforms implemented in 2010 and 2012 significantly contributed to competitiveness gains. The paper also argues that the drop in 
domestic demand and the greater export orientation of firms since the crisis were other important drivers of the recent Spanish export performance.

Cross-country panel regressions allow quantifying the near-term impact of greater labor market flexibility on export growth. For Spain, the 2010 and 2012 labor market reforms are estimated to account for nearly one-tenth to above one-quarter of the real export growth rate from 2010 to 2013 . More generally, the panel data analysis implies that relaxing employment protection legislations in advanced countries, from "highly stringent" to "slightly stringent", is associated with an improvement in the real export growth rate, in a range of approximately 2 to 7 percentage points. These results arguably reflect the effects on competitiveness of labor reforms.

This paper is related to two strands of literature. First, the paper is related to previous work on the recent evolution and drivers of Spanish exports (Myro, 2015 and 2018; Gonzalez Sanz and Machuca, 2015; Prades and García, 2015; Bank of Spain, 2016 and 2017; De Lucio et al., 2017 and 2018; Almunia et al., 2018; Eppinger et al., 2018; European Commission, 2018). In contrast to the bulk of that literature, this paper emphasizes the contribution of the 2010 and 2012 labor market reforms to competitiveness gains, and it attempts to quantify the direct impact of those reforms on Spain's export growth. ${ }^{2}$ Second, while other work has assessed the macroeconomic effects of labor market reforms (see, e.g., IMF, 2016), this paper is also particularly connected to the empirical literature on the impact of such reforms on the external sector. By documenting a positive impact of labor market reforms on exports, this paper helps to rationalize the positive effect of labor reforms on the current account reported in IMF (2018) and other papers cited therein.

The rest of the paper is organized as follows. Section II describes the recent evolution of exports of goods and services, comparing it with pre-crisis years and analyzing exports across sectors. Section III examines key drivers of export growth using a regression-based framework and simple counterfactual experiments, complemented with further analysis of data and insights from related literature. Section IV takes a closer look at the link between employment protection regulation and export performance, using cross-country panel regressions to quantify the contribution of recent Spanish labor market reforms to export growth. Section V provides some conclusions.

\section{RECENT EVOLUTION OF SPANiSh EXPORTS: A BRIEF DESCRIPTION}

\section{The strong performance reflects an increase in real exports of goods and services.} Growth of export values after the crisis reflected to a large extent a strong recovery in export volumes, especially during 2010 and 2011. More recently, real export growth has remained healthy and remarkably stable, at almost 5 percent since 2013. In real terms, the average

\footnotetext{
${ }^{2}$ Bank of Spain (2016) includes an illustration of macroeconomic effects of the labor market reforms, based on Andrés et al.'s (2017) dynamic stochastic general equilibrium model for an open economy.
} 
annual growth rate of goods exports increased from 4.5 percent in 2001-07 to 5.4 percent in 2010-17. And for services, the average annual growth rate surged from 2.9 to 4.3 percent over the same periods.

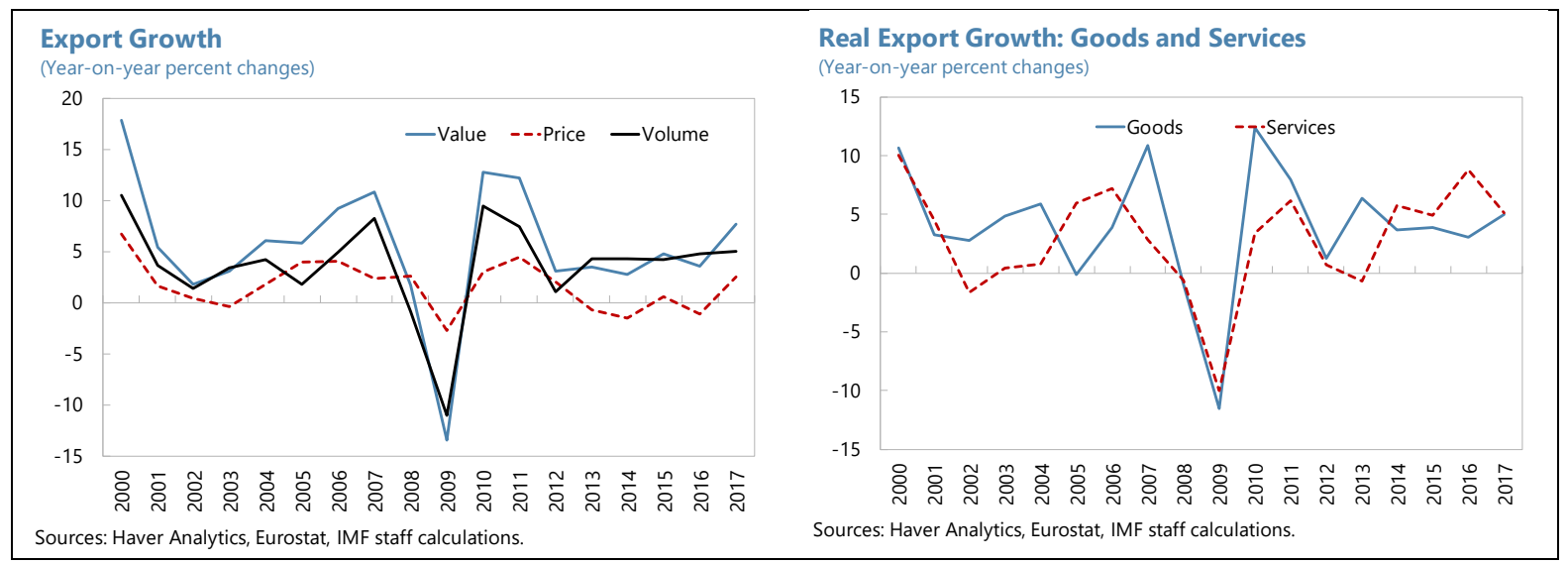

\section{Enhanced export growth was generalized} across the main product groups. The three broad categories of products-consumption, intermediate, and capital goods - exhibited higher average annual growth rates in 2010-17 compared to 2001-07. But the most notable upgrade was observed among capital goods, for which the annual growth rate roughly doubled in the most recent period.

\section{Since 2007, export values increased in almost}

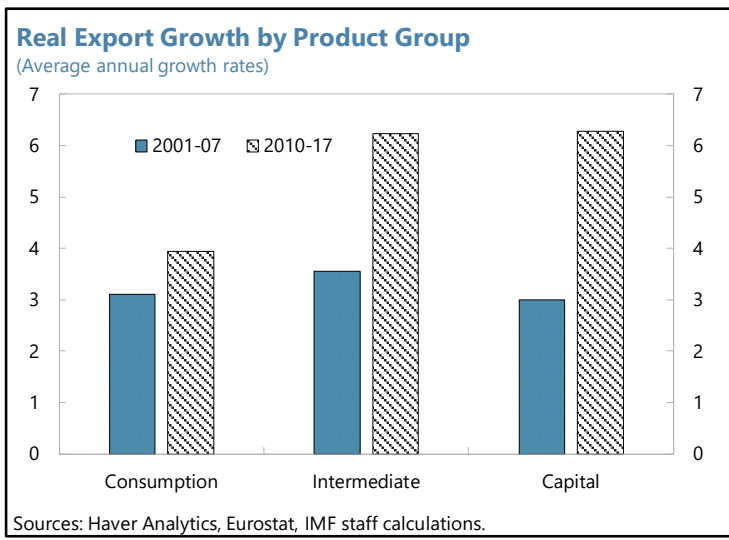

all goods-producing industries. Some of the overperforming industries included foods, beverages, and tobacco; chemicals; and non-durable consumption goods, such as textiles. These three sectors have increased their shares in total exports since 2007, while the shares of durable consumption goods, vehicles, and (to a lesser extent) capital goods have declined. These changes reveal a somewhat more diversified composition of exports across major industries. It is also worth noting that despite the recent reduction in the export share of vehicles, partly linked to declining sales to the United Kingdom, Spain has become the second-biggest car exporter in continental Europe. At a more granular level, automobiles have consolidated as Spain's top export product. 


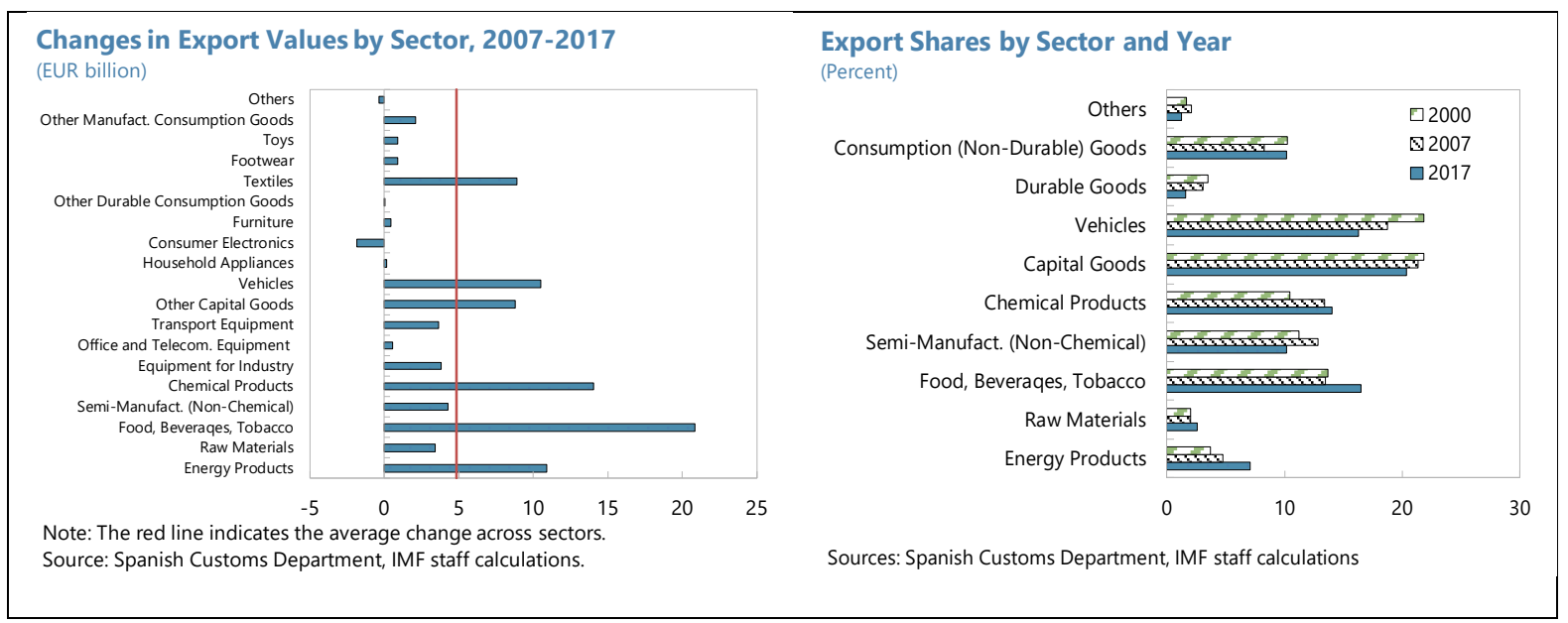

Export quality does not appear to have improved over the past decade. Spain's export quality declined between 2007 and 2014, particularly across manufactures, according to a measure of export quality based on unit values but adjusted for the impact of production costs and pricing strategies (Henn et al., 2017). Using another measure of export quality, the European Commission (2018a) finds that Spain ranked low compared to euro-area peers over 2005-2016. A third metric known as the Economic Complexity Index supports those findings. However, the technological content of Spanish exports has been stable and concentrated in medium-high technology goods (Grinberg, 2017).

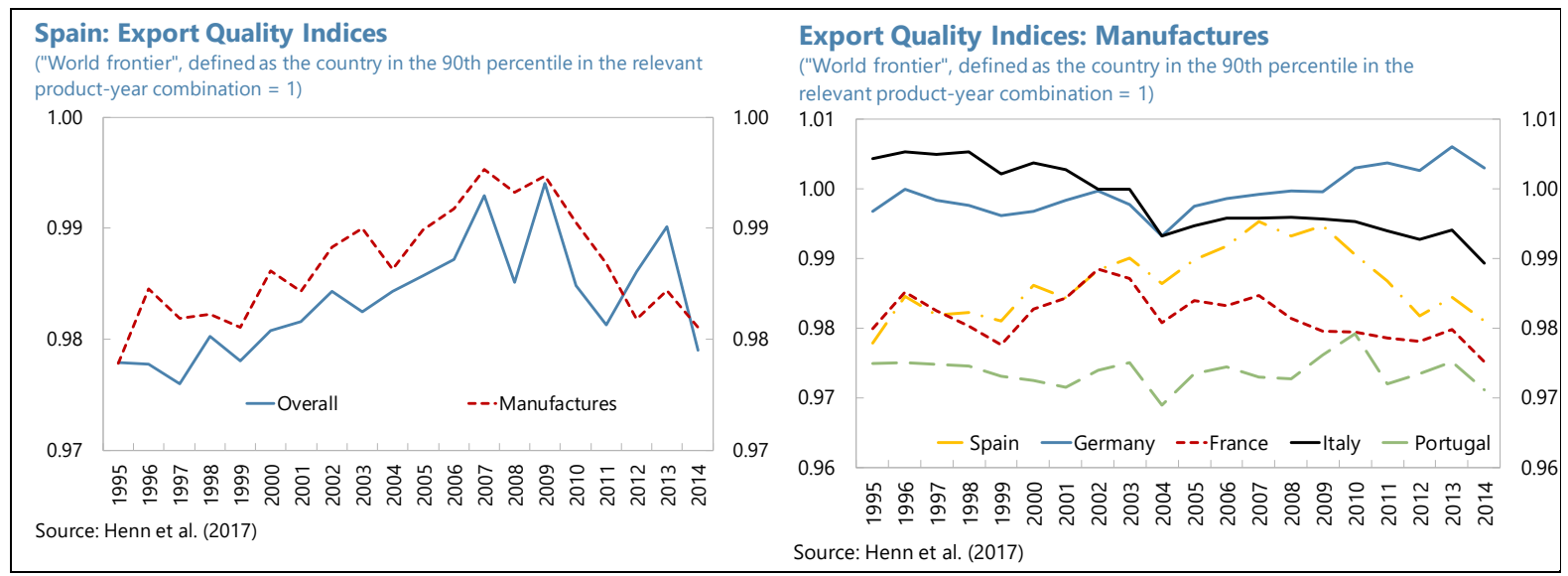

Spain's participation in global value chains (GVCs) is relatively low. Using data from the world input-output database, Prades and Villanueva (2017) find that the participation of Spain in global value chains is still below the international average. This is mainly because its exports tend to be close to the good or service of final consumption; in other words, the bulk of Spanish exports are close to the retail end of the value chain.

Strong export growth of services has been broad-based across sectors. Spain accounts for less than 3 percent of the world's total services exports, but that share started to increase since 2016, after declining in previous years. The average annual growth of tourism receipts 
accelerated in 2010-17 compared to 2001-07. Even though part of that improvement was linked to diverted tourism from competing destinations (in particular, security-troubled countries in North Africa and the Middle East), Spain has structural strengths in the tourism sector, including upgraded ICT infrastructure, and it has ranked first in the two most recent editions of the World Economic Forum (WEF)'s Travel and Tourism Competitiveness Report. Meanwhile, exports of non-travel services increased from 4 percent of GDP in 2007 to 5.4 percent of GDP in 2017, driven in part by an expansion to new markets, supported by government-backed market development plans, and the growth of "other business services" in areas such as engineering, consultancy, and advertising (Bank of Spain, 2018).

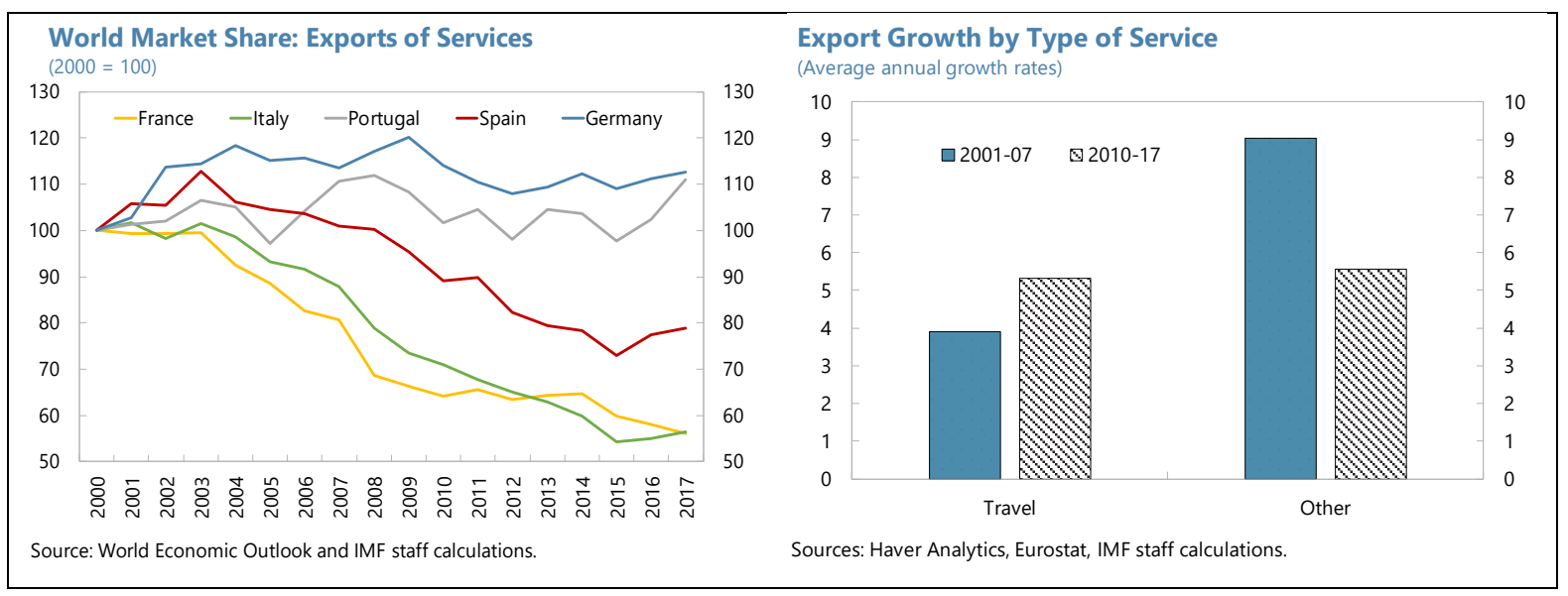

\section{ASSESSING THE DRIVERS OF EXPORT GROWTH}

\section{A regression allows quantifying the contribution of foreign demand and}

competitiveness to export growth. A standard export equation is estimated, linking the growth of total export volumes of goods and services to changes in external demand (exportweighted real GDP growth of destination markets) and the real effective exchange rate based on unit labor costs (ULC-based REER). The latter captures the role of cost competitiveness and is preferred to other alternative measures given the evidence of a robust empirical relationship between exports and the ULC-based REER (see, e.g., Bayoumi et al., 2011, and Bobeica et al., 2016). The regression uses quarterly data for 1995:Q1-2017:Q4 and includes a dummy variable to control for an outlier - the sharp contraction in exports in 2008:Q4. All the variables are expressed in log differences. The estimated coefficients in Table 1 , column 1 , have the expected signs and are statistically significant. 


\begin{tabular}{|c|c|c|}
\hline Sample: 1995Q1-2017Q4 & & \\
\hline Dependent variable: $\Delta \operatorname{Ln}\left(\right.$ Real Exports $\left.s_{t}\right)$ & $(1)$ & (2) \\
\hline$\Delta \operatorname{Ln}\left(\right.$ Foreign Demand $\left.d_{t}\right)$ & $\begin{array}{c}2.560^{* \star *} \\
(0.320)\end{array}$ & $\begin{array}{c}2.870^{* * *} \\
(0.303)\end{array}$ \\
\hline$\Delta \operatorname{Ln}\left(\right.$ ULC-Based REER $\left.\mathrm{t}_{\mathrm{t}-1}\right)$ & $\begin{array}{c}-0.302^{* *} \\
(0.145)\end{array}$ & $\begin{array}{c}-0.248^{*} \\
(0.138)\end{array}$ \\
\hline$\Delta \operatorname{Ln}\left(\right.$ Private Consumption $\left.\mathrm{t}_{\mathrm{t}-1}\right)$ & & $\begin{array}{c}-0.363^{*} \\
(0.189) \\
\end{array}$ \\
\hline Observations & 90 & 90 \\
\hline Adj. $R^{2}$ & 0.567 & 0.577 \\
\hline
\end{tabular}

\section{External demand was a key driver of exports, and the post-crisis contribution of competitiveness was positive. Based on the regression results (Table 1, column 1), a} decomposition of export growth from 1999 to 2017 indicates that foreign demand explains the bulk of that growth in most periods. Importantly also, the contribution of cost competitiveness switched from negative before the crisis to positive afterwards, reflecting the generally declining trend of the ULC-based REER since mid-2008, driven by an internal devaluation process that improved Spain's ULC relative to its trading partners. ${ }^{3,4}$ Specifically, the adjustment of Spain's own ULC has reflected wage moderation since 2010, declining employment until 2013, and more recently, a strong recovery in real GDP. This simple decomposition framework suggests that improved competitiveness accounted for about 15 percent of the average annual growth rate of real exports over 2010-13.

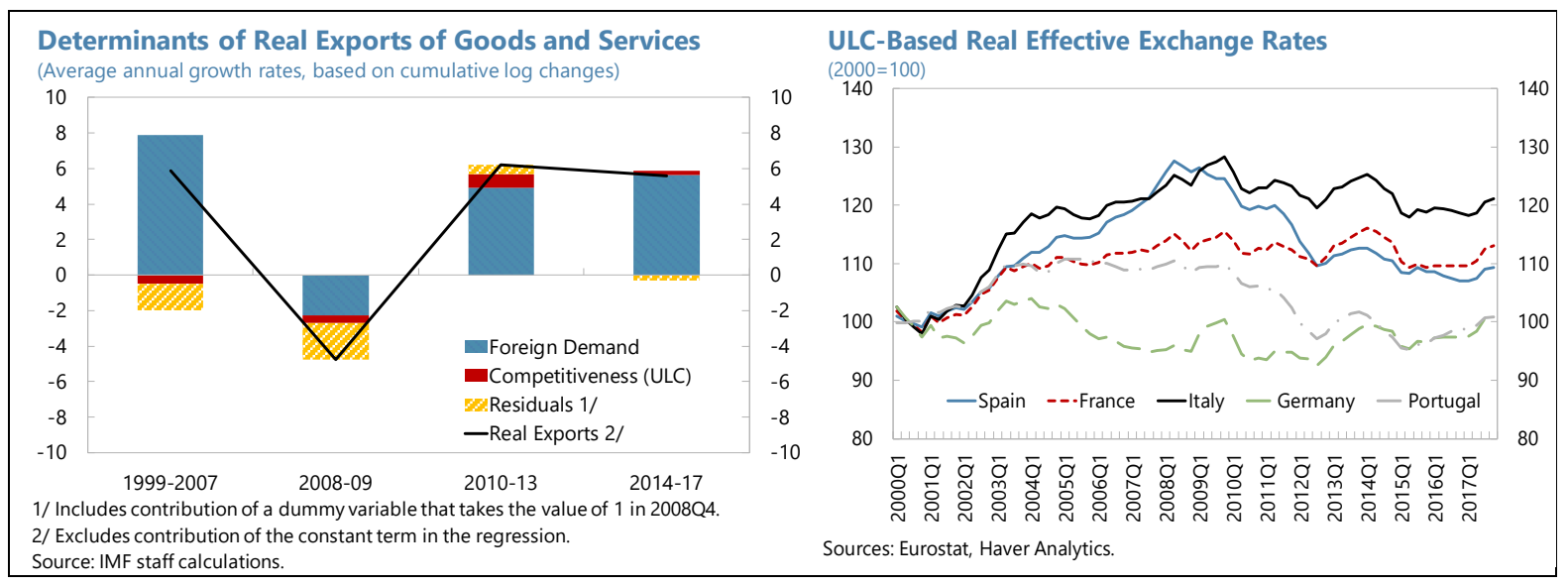

\footnotetext{
${ }^{3}$ Bluedorn and Lin (2017) investigate the recent adjustment of the ULC-based REERs in euro area countries.

${ }^{4}$ Spain's competitiveness gains since 2008 are larger when measured with the ULC-based REER than with other price competitiveness indicators (Prades and García, 2015; Bank of Spain, 2016).
} 
Recent labor market reforms significantly contributed to competitiveness gains. Spain implemented labor market reforms in 2010 and 2012 to facilitate the adjustment of wages in a high-unemployment context. ${ }^{5}$ According to estimates from the OECD (2014), the 2012 labor market reforms (together with the 2012-14 Agreement for Employment and Collective Bargaining, signed by social agents in early 2012) induced a drop in the growth of Spain's business-sector ULC of between 1.2 percentage points and 1.9 percentage points from 2011:Q4 to 2013:Q2; that is, an average quarterly drop of between 0.2 percentage points to above 0.3 percentage points. ${ }^{6}$ Using as baseline scenario the regression-based decomposition of export growth presented above, and assuming that the OECD's estimated average quarterly effects of the 2012 labor market reforms on ULC remained in place until 2017, an illustrative counterfactual analysis suggests that the contribution of competitiveness gains to export growth over 2012-17 would have significantly reduced in the absence of the reforms - at least, by around one-half relative to the baseline. If, instead, the OECD's estimated effects of the reforms on ULC had lasted only until 2013, then the contribution of competitiveness to export growth over 2012-13 would have reduced by at least one-quarter compared to the baseline scenario. An additional simple counterfactual experiment, assuming greater labor market flexibility since 2008, is described in Box 1.

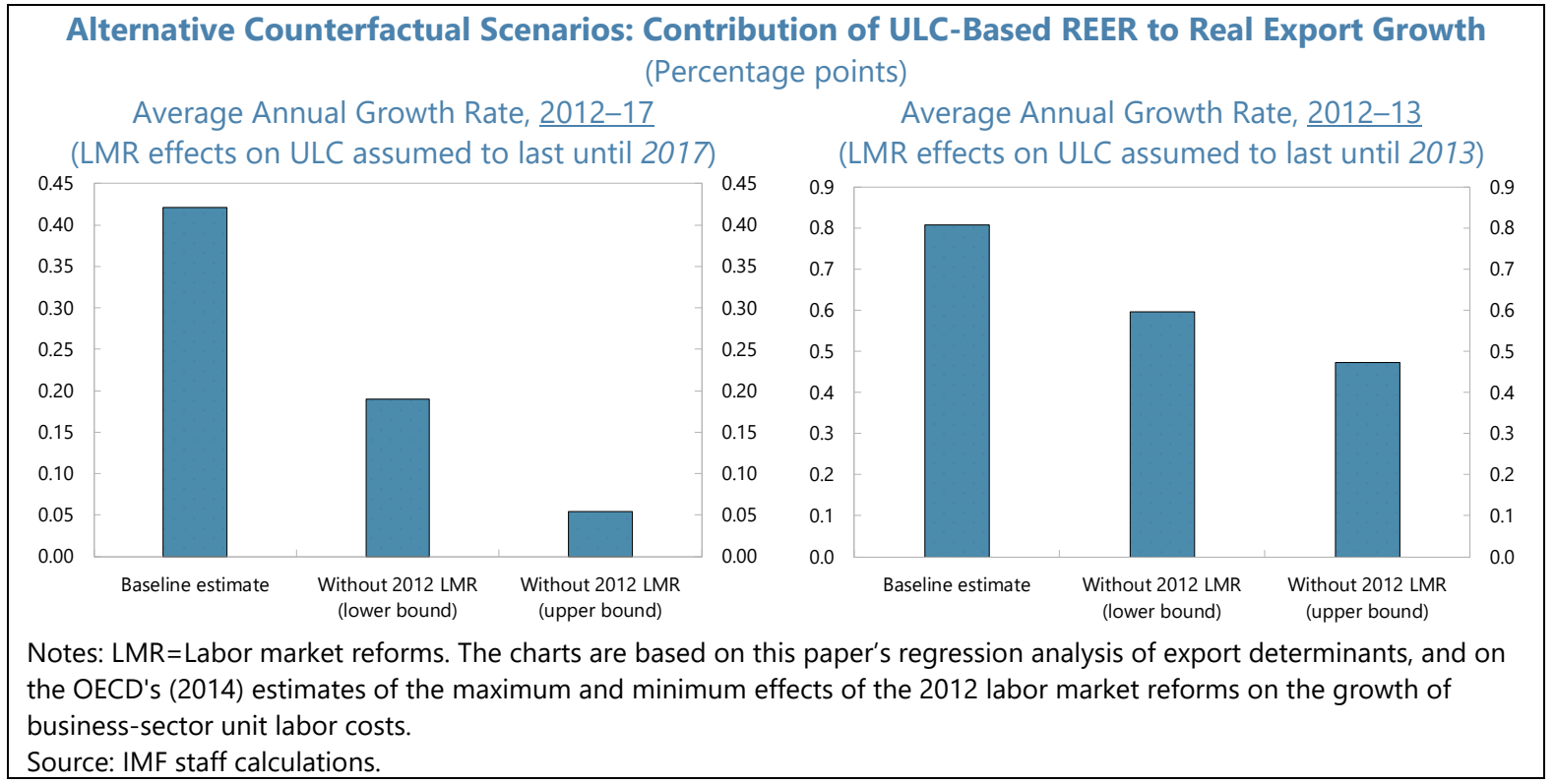

\footnotetext{
${ }^{5}$ For discussions on the reforms and their macroeconomic effects, see e.g. Izquierdo et al. (2013), Dao (2015), Doménech et al. (2016), and Andrés et al. (2017).

${ }^{6}$ The OECD's (2014) estimates are based on regression-discontinuity models, in which the effects of the reform are identified through discontinuous patterns occurring at the time of its implementation and the business cycle is modelled through observable controls and nonlinear time trends.
} 
Box 1. Counterfactual: Competitiveness and Exports with more Flexible Wages Since 2008

With greater wage flexibility since the onset of the crisis, unit labor costs (ULC) would have been even lower. Using a quarterly Structural VAR model for Spain featuring macro and labor market variables, identified with long-run and sign restrictions, Doménech et al. (forthcoming) estimate structural shocks reflecting rigidities in wage formation. They find that these "wage shocks" became smaller particularly since 2012, coinciding with the enforcement of the labor reform in early 2012. In a counterfactual modelbased scenario, Doménech et al. shut down the wage shocks for the 2008-11 period. In this scenario of greater wage flexibility since 2008:Q1, Spain's ULC would have declined relative to the actual series by more than 2 percentage points on impact, and by around 4 percentage points per quarter over the medium term.

Exports would have benefited from enhanced wage flexibility in the wake of the crisis. Assuming the alternative path for the ULC described above and using as baseline scenario this paper's regression-based decomposition of export growth (see main text), a simple counterfactual analysis suggests that the contribution of competitiveness gains to export growth in 2008-11 would have increased considerably as a result of greater wage flexibility. In this counterfactual experiment, the contribution of competitiveness (ULCbased REER) to the average annual export growth over 2008-2011 would have been two to nearly four times as large as in the baseline scenario. This range reflects the confidence bands around the central estimates of the alternative ULC path.

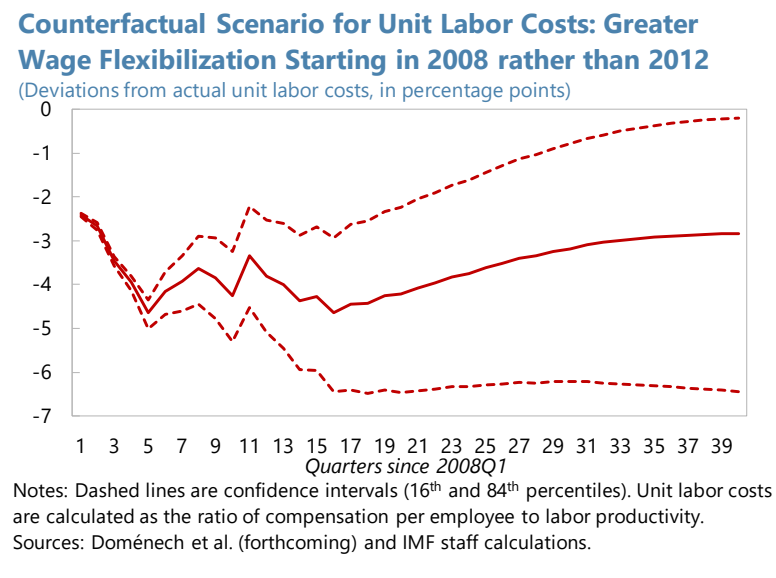

Counterfactual Scenario for Unit Labor Costs: Greater Wage Flexibilization Starting in 2008 rather than 2012 (Deviations from actual unit labor costs, in percentage points)

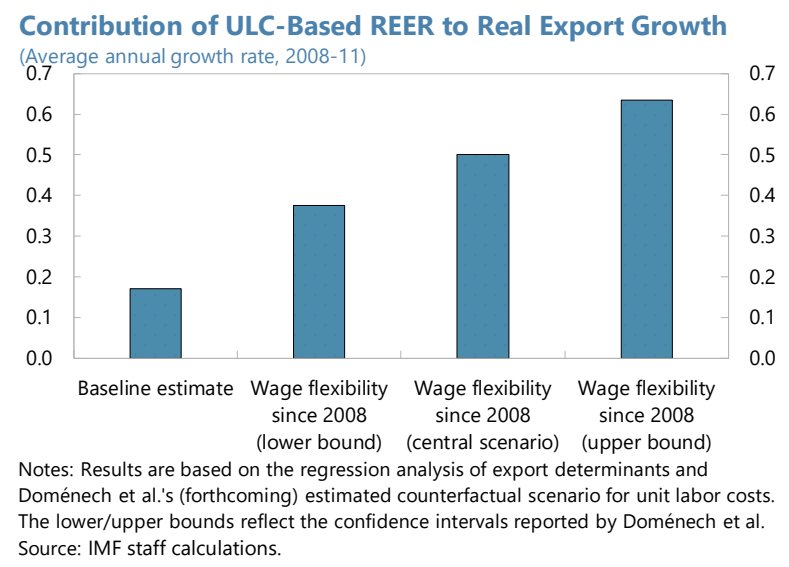

Spanish exports have increasingly oriented to non-EU markets. In recent years, exports expanded more rapidly toward non-EU countries than toward partners within the bloc. The EU's share in Spanish goods exports declined from 73.1 percent in 2000 to 70.9 percent in 2007, and even further to 66.3 percent in 2017. Such declines were slightly more pronounced in the case of the euro area's share, which fell from 58.1 percent in 2007 to 52.7 percent in 2017. Over 2010-2017, the annual real growth rate of goods exports to the EU was 3.9 percent, compared to 8.6 percent for exports outside the EU. These trends have allowed Spain to narrow its geographic diversification gap with France, as reflected by a market concentration index, though it still lags behind Italy and Germany. 


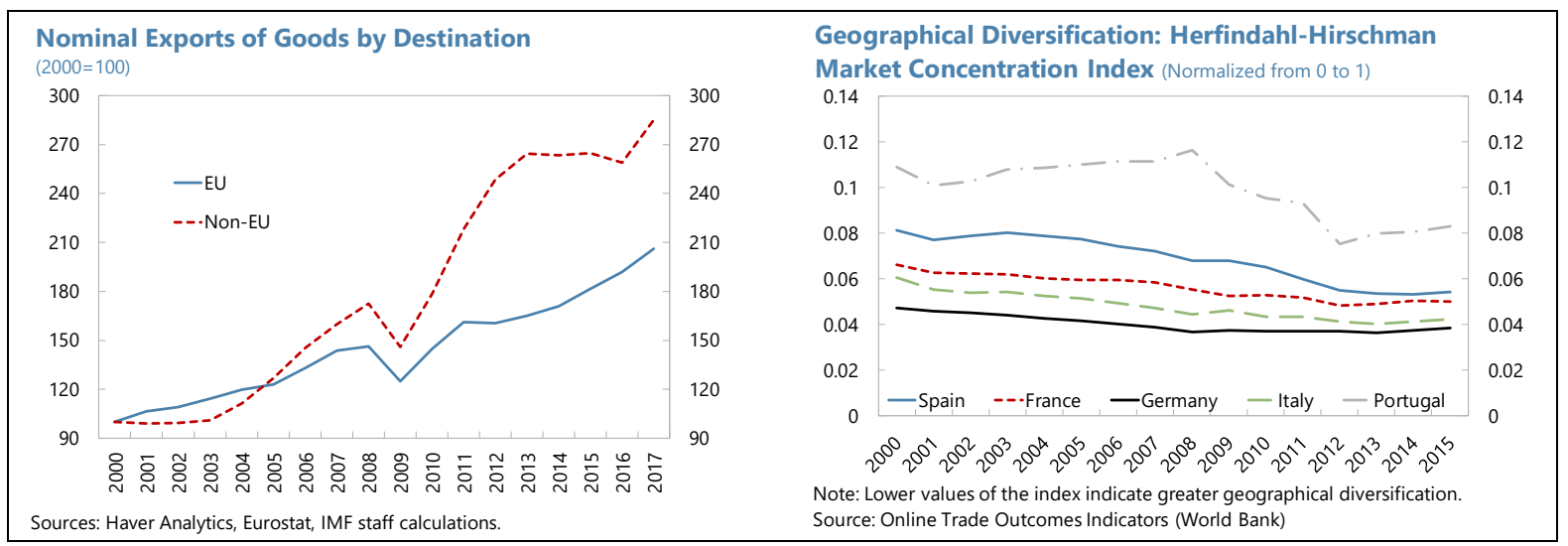

The impulse from external demand benefited from geographic diversification. Spanish exports have structurally been more oriented to relatively slow-growing countries (González Pandiella, 2015; Alvarez-López and Myro, 2018). But since around 2007, exports have reoriented to relatively fast-growing countries, including emerging and developing markets in Asia, Latin America, North Africa, and the Middle East. This pattern becomes apparent when comparing the "growth orientation" of exports by trading partner, focusing on Spain's export shares from 2007 and 2016.

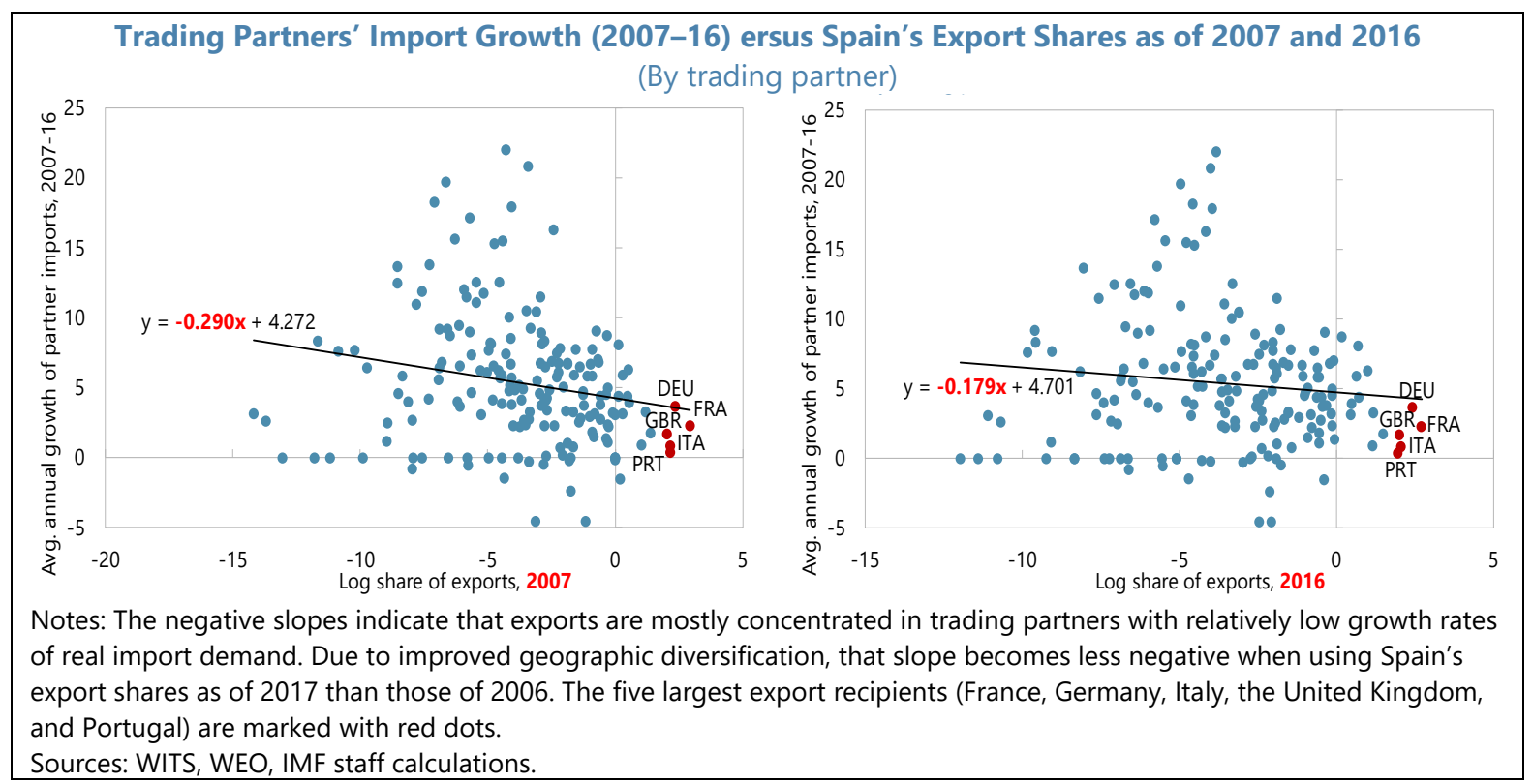

Other drivers of post-crisis export growth were the slump in domestic demand and the greater export orientation of Spanish firms. Given the sharp decline in domestic demand, particularly until 2013, firms faced strong incentives to find buyers abroad: Almunia et al. (2018) empirically document that, on average, Spanish manufacturing firms replaced around one-third of their lost domestic sales with sales in foreign markets over 2009-13. This link between low domestic demand and export growth seems to be captured by the statistically significant role of (lagged) domestic private consumption in a standard export equation for Spain (see Table 1 above, column 2). The large increase in the number of exporting firms further indicates that, since the crisis, firms have stepped up efforts for selling in foreign 
markets. Notably, the number of exporters that have been active for at least four consecutive years rose by nearly one-third between 2007 and 2017. The enhanced internationalization of Spanish firms has been arguably supported by regained competitiveness. ${ }^{7}$

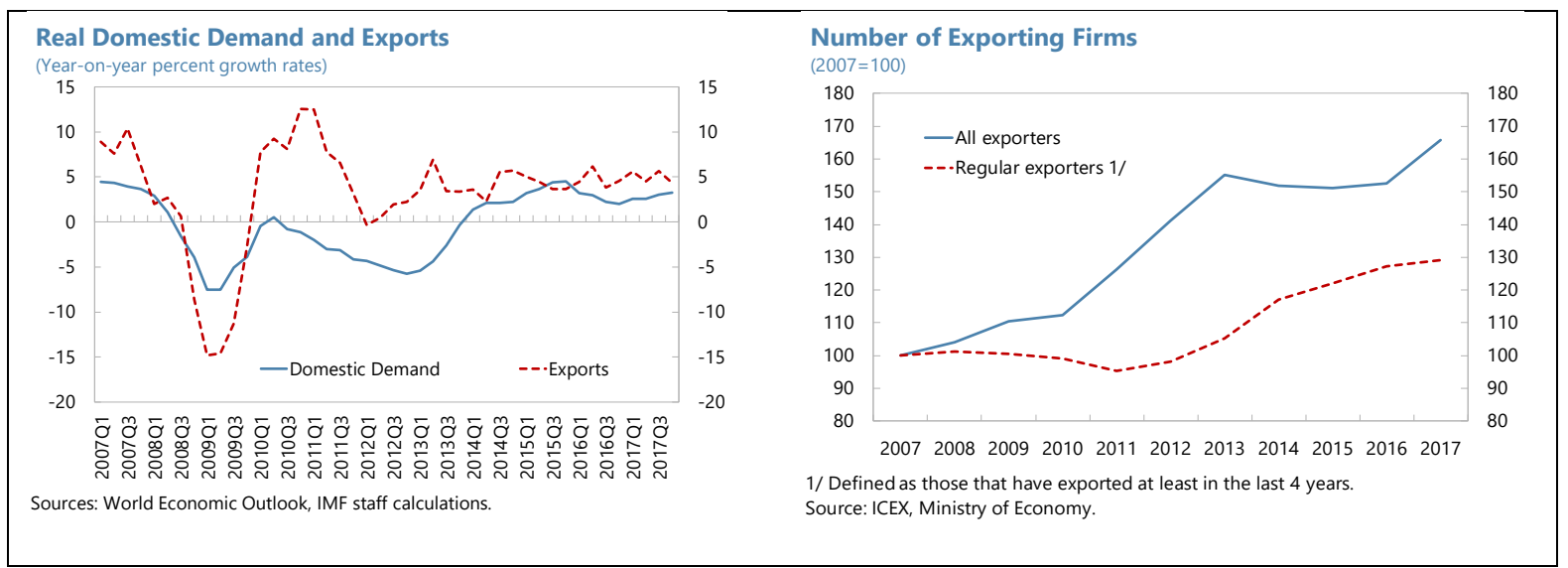

\section{A Closer LoOK AT THE ROLE OF LABOR MARKET REFORMS: IMPACT OF EMPLOYMENT PROTECTION ON EXPORTS IN A CROSS-COUNTRY FRAMEWORK}

Cross-country panel regressions shed more light on the relationship between labor market flexibility and export growth. Additional analysis evaluates if labor market flexibility has statistically significant near-term effects on export growth. These effects could be explained by improved cost competitiveness, as discussed above, or by enhanced productivity growth (Bassanini et al., 2009). The analysis focuses on the impact of less or more stringent hiring and firing regulations (or loosely speaking, higher or lower "labor market flexibility"), measured by four alternative OECD indicators of employment protection legislation and a survey-based indicator of 'hiring and firing practices' from the WEF's Global Competitiveness Report. The use of panel data helps to control for several factors in the regressions, captured by fixed effects, overcoming a limitation that would arise in the context of country-specific regressions.

The estimation uses annual data for a sample of $\mathbf{2 6}$ advanced countries, including Spain. ${ }^{8}$ Depending on the availability of data for the labor market flexibility indicators, the sample period starts in 1985, 1998, or 2006; and it ends in 2016. The Appendix provides more details. The baseline estimating equation is:

\footnotetext{
${ }^{7}$ Anecdotal evidence highlights the importance of competitiveness gains and firms' foreign expansion for the Spanish economic recovery. See Financial Times (2016 and 2017), The Economist (2017), and El País (2018).

${ }^{8}$ The countries in the estimation sample are: Australia, Austria, Belgium, Canada, Czech Republic, Denmark, Finland, France, Germany, Greece, Iceland, Ireland, Italy, Japan, Korea, Luxembourg, the Netherlands, New Zealand, Norway, Portugal, Slovak Republic, Spain, Sweden, Switzerland, United Kingdom, and the United States. The regressions incorporating the WEF's "hiring and firing practices" indicator exclude Korea.
} 


$$
\Delta \ln E X_{i, t}=\alpha_{i}+\gamma_{t}+\beta L M I_{i, t}+\delta\left(L M I_{i, t} * \text { LowGrowt }_{i, t}\right)+\theta \sum_{k=0} X_{i, t-k}+\varepsilon_{i, t},
$$

where $i$ and $t$ denote countries and years, respectively; the dependent variable, $\Delta \ln E X$, is the log change of either total real exports or real exports of goods only; $L M I_{i, t}$ is an indicator of labor market flexibility (the key regressor of interest); LowGrowt $h_{i, t}$ is a dummy variable that takes the value of 1 if a country's real GDP growth falls one-standard-deviation below its in-sample average ("low growth"), and 0 otherwise; and $X_{i, t-k}$ are control variables, including the log change of trading partners' real import demand (proxy for external demand) and the lagged log change of the ULC-based REER. As in the IMF (2016) analysis of macroeconomic effects of labor market reforms, the following controls are also included: lagged economic growth, a lagged indicator of recessions or economic crises (captured by negative real GDP growth), and a lag of $L M I_{i}$. The regression also incorporates country and year fixed effects $\left(\alpha_{i}\right.$ and $\left.\gamma_{t}\right)$, and $\varepsilon_{i, t}$ represents the residuals. ${ }^{9}$ The dummy LowGrowt $h_{i, t}$ is introduced to allow for nonlinearities, which could be related to differentiated responsiveness of labor market variables and output (and hence of ULC-based competitiveness measures) to labor market reforms during recessions. ${ }^{10}$ Although the use of controls attempts to mitigate concerns about omitted variables, it is difficult to fully address endogeneity issues in these regressions. So, the estimated $\beta$ and $\delta$ coefficients may not be interpreted as implying causal effects. Some robustness exercises are discussed below and in the Appendix.

\section{The results show that less stringent employment protection is associated with faster} export growth (Table 2). The negative coefficients on the OECD's employment protection indicators and the positive coefficients on the WEF's indicator reveal that less stringent hiring and firing regulations support faster growth of real exports. While there are a few differences across the regressions with total exports as dependent variable (columns 1-5) and those with goods exports as dependent variable (columns 6-10), the bulk of the evidence linked to the employment protection indicators suggests that: (i) the effects are mostly statistically significant for regulations governing individual and/or collective dismissals of workers with permanent contracts; (ii) regulations on temporary contracts are not associated with export growth in a significant way; and (iii) the positive effects of less stringent employment protection on exports strengthen with low economic growth, as implied by the statistically significant interaction terms of the labor market flexibility indicators with the Low Growth dummy. Moreover, two key control variables (growth of trading partners' import demand and lagged ULC-based REER appreciation) have the expected signs and tend to be statistically significant.

\footnotetext{
${ }^{9}$ The estimation uses two-way clustering at the country and at the year level. Clustering the standard errors only at the country level does not substantially change the results.

${ }^{10}$ For further discussion and evidence on such nonlinearities, see Bentolilla and Bertola (1990), Cacciatore et al. (2016), and Duval and Furceri (2018). Nonlinearities in the context of this analysis could also arise if the competitiveness effects of labor market flexibility become particularly beneficial with depressed domestic demand, facilitating firms' efforts to compensate lost domestic revenues with sales in foreign markets.
} 


\begin{tabular}{|c|c|c|c|c|c|c|c|c|c|c|}
\hline \multirow[t]{2}{*}{ Dependent variable: } & \multicolumn{5}{|c|}{ Log change in real exports } & \multicolumn{5}{|c|}{ Log change in real exports of goods } \\
\hline & $(1)$ & $(2)$ & $(3)$ & (4) & $(5)$ & (6) & $(7)$ & $(8)$ & $(9)$ & $(10)$ \\
\hline $\begin{array}{l}\text { OECD Employment protection: individual } \\
\text { and collective dismissals (permanent contracts) }\end{array}$ & $\begin{array}{l}-0.062^{* *} \\
(0.031)\end{array}$ & & & & & $\begin{array}{l}-0.072^{\star *} \\
(0.032)\end{array}$ & & & & \\
\hline $\begin{array}{l}\text { OECD Employment protection: individual } \\
\text { and collective dismissals (permanent contracts) * LowGrowth }\end{array}$ & $\begin{array}{l}-0.007^{* *} \\
(0.003)\end{array}$ & & & & & $\begin{array}{l}-0.007^{* *} \\
(0.003)\end{array}$ & & & & \\
\hline $\begin{array}{l}\text { OECD Employment protection: individual } \\
\text { dismissals (permanent contracts) }\end{array}$ & & $\begin{array}{l}-0.049^{*} \\
(0.026)\end{array}$ & & & & & $\begin{array}{l}-0.061^{\star *} \\
(0.028)\end{array}$ & & & \\
\hline $\begin{array}{l}\text { OECD Employment protection: individual } \\
\text { dismissals (permanent contracts) * LowGrowth }\end{array}$ & & $\begin{array}{l}-0.007^{\star *} \\
(0.003)\end{array}$ & & & & & $\begin{array}{l}-0.006^{*} \\
(0.003)\end{array}$ & & & \\
\hline $\begin{array}{l}\text { OECD Employment protection: average notice for } \\
\text { no-fault individual dismissal (permanent contracts) }\end{array}$ & & & $\begin{array}{l}-0.010 \\
(0.009)\end{array}$ & & & & & $\begin{array}{l}-0.017^{* *} \\
(0.007)\end{array}$ & & \\
\hline $\begin{array}{l}\text { OECD Employment protection: average notice for } \\
\text { no-fault individual dismissal (permanent contracts) * LowGrowth }\end{array}$ & & & $\begin{array}{l}-0.007^{\star \star \star} \\
(0.002)\end{array}$ & & & & & $\begin{array}{l}-0.007^{\star *} \\
(0.003)\end{array}$ & & \\
\hline $\begin{array}{l}\text { OECD Employment protection: temporary } \\
\text { employment }\end{array}$ & & & & $\begin{array}{l}-0.007 \\
(0.013)\end{array}$ & & & & & $\begin{array}{l}-0.013 \\
(0.009)\end{array}$ & \\
\hline $\begin{array}{l}\text { OECD Employment protection: temporary } \\
\text { employment * LowGrowth }\end{array}$ & & & & $\begin{array}{l}-0.005 \\
(0.003)\end{array}$ & & & & & $\begin{array}{l}-0.004 \\
(0.004)\end{array}$ & \\
\hline $\begin{array}{l}\text { WEF's Global Competitiveness Index: } \\
\text { Hiring and firing practices }\end{array}$ & & & & & $\begin{array}{l}0.033^{* *} \\
(0.014)\end{array}$ & & & & & $\begin{array}{c}0.028 \\
(0.020)\end{array}$ \\
\hline $\begin{array}{l}\text { WEF's Global Competitiveness Index: } \\
\text { Hiring and firing practices * LowGrowth }\end{array}$ & & & & & $\begin{array}{l}-0.002 \\
(0.003)\end{array}$ & & & & & $\begin{array}{l}-0.002 \\
(0.004)\end{array}$ \\
\hline Lagged ULC-Based REER (log change) & $\begin{array}{l}-0.119^{* *} \\
(0.048)\end{array}$ & $\begin{array}{l}-0.128^{* * *} \\
(0.046)\end{array}$ & $\begin{array}{c}-0.133^{* * *} \\
(0.045)\end{array}$ & $\begin{array}{c}-0.126^{\star \star *} \\
(0.047)\end{array}$ & $\begin{array}{l}-0.070 \\
(0.097)\end{array}$ & $\begin{array}{l}-0.088 \\
(0.062)\end{array}$ & $\begin{array}{l}-0.117^{*} \\
(0.060)\end{array}$ & $\begin{array}{l}-0.122^{\star *} \\
(0.059)\end{array}$ & $\begin{array}{l}-0.115^{*} \\
(0.061)\end{array}$ & $\begin{array}{l}-0.023 \\
(0.124)\end{array}$ \\
\hline Trading partners' real import demand (log change) & $\begin{array}{l}0.843^{\star \star *} \\
(0.198)\end{array}$ & $\begin{array}{l}0.714^{\star \star *} \\
(0.160)\end{array}$ & $\begin{array}{l}0.691^{\star \star *} \\
(0.158)\end{array}$ & $\begin{array}{l}0.688^{\star \star \star} \\
(0.158)\end{array}$ & $\begin{array}{l}0.988^{\star * \star} \\
(0.309)\end{array}$ & $\begin{array}{l}0.708^{* * *} \\
(0.186)\end{array}$ & $\begin{array}{l}0.708^{\star \star \star} \\
(0.186)\end{array}$ & $\begin{array}{l}0.676^{\star \star \star} \\
(0.185)\end{array}$ & $\begin{array}{l}0.690^{* \star *} \\
(0.187)\end{array}$ & $\begin{array}{l}0.990^{\star \star *} \\
(0.336)\end{array}$ \\
\hline Observations & 448 & 496 & 496 & 496 & 225 & 448 & 496 & 496 & 496 & 225 \\
\hline Adj. R-squared & 0.599 & 0.593 & 0.595 & 0.586 & 0.634 & 0.529 & 0.523 & 0.524 & 0.523 & 0.542 \\
\hline Country FE & YES & YES & YES & YES & YES & YES & YES & YES & YES & YES \\
\hline Year FE & YES & YES & YES & YES & YES & YES & YES & YES & YES & YES \\
\hline $\begin{array}{l}\text { Notes: Statistical significance denoted by }{ }^{* *} \text { for } 1 \%,{ }^{* *} \text { for } 5 \% \text {, a } \\
\text { countries, except for columns (5) and (10) that include } 25 \text { countri } \\
\text { indicators vary from } 0 \text { (least restrictive) to } 6 \text { (most restrictive); W } \\
\text { REG3B, and REG3C indicators from the OECD EPL database. Low } \\
\text { otherwise. Other unreported control variables include lagged lab }\end{array}$ & $\begin{array}{l}\text { רd * for } 10 \\
\text { es. The san } \\
\text { EF indicator } \\
\text { Growth is a } \\
\text { or market }\end{array}$ & $\begin{array}{l}\text { \%. Standarc } \\
\text { nple period } \\
\text { varies fror } \\
\text { dummy va } \\
\text { reform indi }\end{array}$ & $\begin{array}{l}\text { errors are } \\
\text { varies dep } \\
\mathrm{m} 0 \text { (worst) } \\
\text { riable that }\end{array}$ & $\begin{array}{l}\text { clusterec } \\
\text { ending o } \\
\text { to } 7 \text { (bes } \\
\text { takes the } \\
\text { ged real }\end{array}$ & $\begin{array}{l}\text { at the cou } \\
\text { data availa } \\
\text { OECD's " } \\
\text { alue of } 1 \text { ir }\end{array}$ & $\begin{array}{l}\text { y-year le } \\
\text { ility; in m } \\
\text { erage no } \\
\text { ears of b }\end{array}$ & $\begin{array}{l}\text { The samp } \\
\text { t cases it cc } \\
\text { e" indicato } \\
\text { ow-averag } \\
\text { economic }\end{array}$ & $\begin{array}{l}\text { le covers } \\
\text { overs } 198 \\
\text { is the av } \\
\text { e real GD } \\
\text { lownturn }\end{array}$ & $\begin{array}{l}6 \text { advance } \\
\text { 2016. OEC } \\
\text { age of REC } \\
\text { growth, an } \\
\text { dicator. }\end{array}$ & 0 \\
\hline
\end{tabular}


The implied amplification effects of employment regulation reforms on export growth are economically important. Based on the point estimates and standard errors of the statistically significant coefficients shown in Table 2, the estimated amplification effects of relaxing hiring and firing regulations from "highly stringent" (a country at the 75 th percentile of the distributions of the OECD's employment protection indicators, or at the 25 th percentile of the WEF indicator) to "slightly stringent" (at the 25 th percentile of the distributions of the OECD indicators, or at the 75th percentile of the WEF indicator) are between nearly 2 percentage points to around 7 percentage points. With low GDP growth, the amplification effects of labor

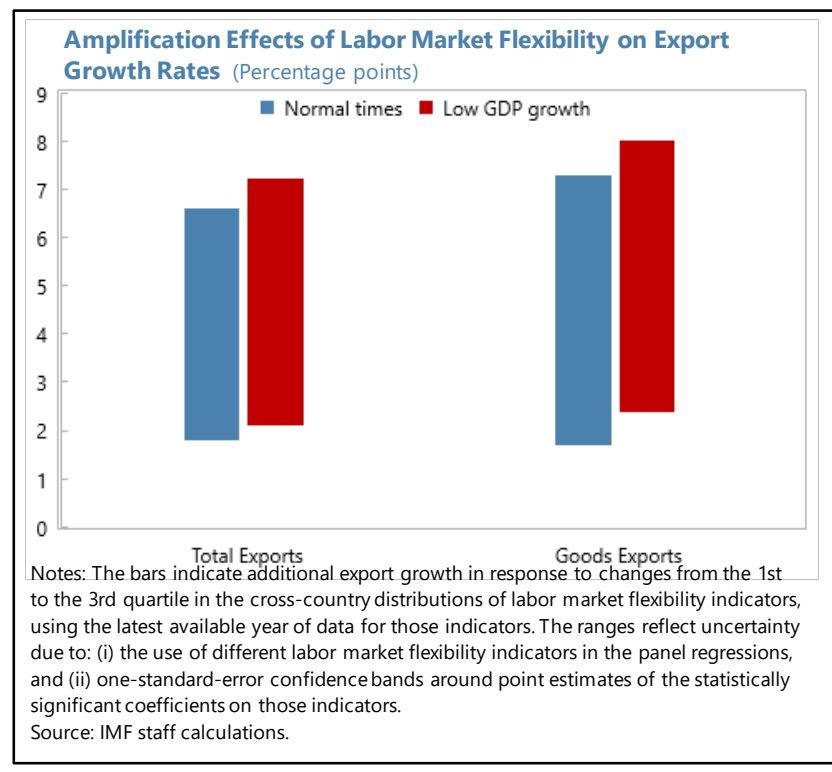
reforms on export growth rates increase somewhat.

For Spain, the reforms of 2010 and 2012 are estimated to account for a non-trivial fraction of export growth over 2010-13. The impact of recent labor market reforms in Spain is quantified by focusing on the statistically significant coefficients on the key regressors of interest (point estimates and one-standard-error confidence bands for $\beta$ and $\delta$ ) and taking into account the cumulative changes in Spain's labor market flexibility indicators between 2010 and 2013 (see Appendix). Overall, the results indicate that the 2010 and 2012 reforms were associated with faster growth of real exports over 2010-13, in the order of around 1 to 4 percentage points. This means that the reforms accounted for nearly one-tenth to above one-quarter of Spain's total export growth rate from 2010 to $2013 .{ }^{11}$

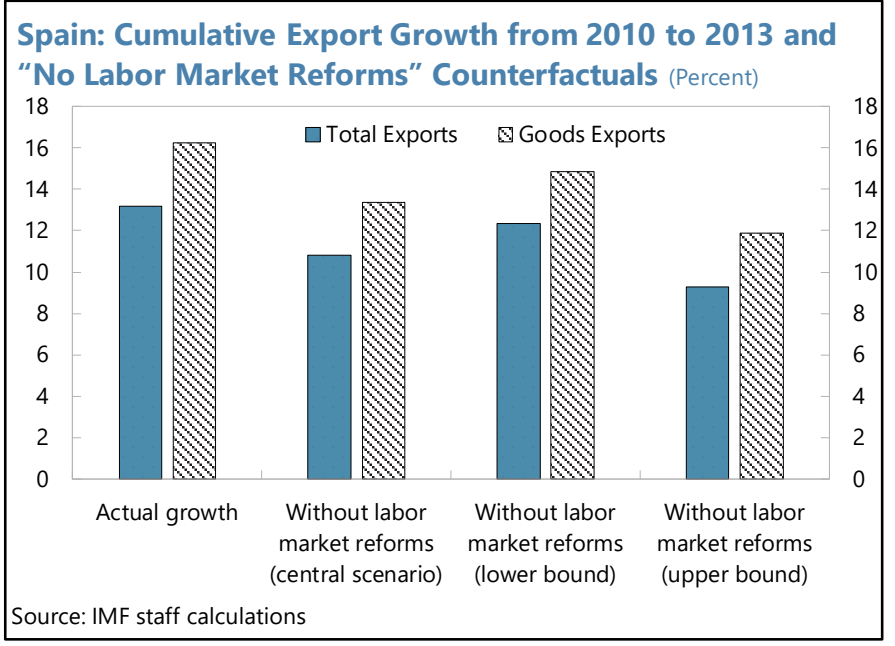

The estimated export gains from labor reforms likely reflect enhanced competitiveness. The empirical results above do not disentangle the channels through which labor market

\footnotetext{
${ }^{11}$ It is worth noting that while the Spanish reforms affected several aspects of the labor market, the flexibility indicators used in the regressions mainly reflect the strictness of regulation on dismissals and hiring.
} 
flexibility enhances export performance. But a simple exercise suggests that cost competitiveness is a key mechanism: incorporating the contemporaneous log change of the ULC-based REER as an additional control variable (and not only its first lag, as in the baseline regressions) largely reduces the significance of the coefficients on the labor market flexibility indicators. ${ }^{12}$ Although labor reforms may also boost exports through productivity gains, this mechanism probably does not play an important role in explaining the estimated coefficients because productivity gains could take some time to materialize, while the regressions in this paper focus on the near-term impact of reforms. ${ }^{13}$

Product market reforms may also be relevant for exports. In another robustness exercise, regressions augmented with OECD indicators of product market regulation reveal in some cases a statistically significant role for these variables, suggesting that enhanced competition in product markets could also help strengthen export performance. ${ }^{14,15}$

\section{Conclusions}

\section{Spain's improved export performance was broad-based across sectors and was driven} by several factors. The main conclusions are the following. First, many sectors contributed to the increasing export volumes of goods and services. Second, the export boom has not been accompanied by improvements in export quality, and Spain's participation in global value chains remains below the international average. Third, external demand has been a key driver of export growth, and the impulse from that factor benefited from higher diversification of destination markets. Fourth, the greater export orientation of Spanish firms, including a significant increase in the number of exporters, was triggered in part by depressed domestic demand. These factors have also played a role in the success of exports. Fifth, the contribution of cost competitiveness to export growth turned positive after the crisis, helped by the effects of the labor market reforms. Finally, according to cross-country

\footnotetext{
${ }^{12}$ In a general equilibrium model for an open economy, Andrés et al. (2017) show that structural reforms, including on the labor market, help competitiveness by reducing producer prices and hence the terms of trade.

${ }^{13}$ On the link between labor market institutions and trade, Cuñat and Melitz (2012) find empirically that countries with more flexible labor markets have a comparative advantage in industries with greater sales volatility. They argue that labor market flexibility favors worker reallocation across firms within an industry. It is an open question whether this mechanism may not only be relevant for comparative advantage, but also for shaping the dynamics of exports.

14 The significance of some labor market flexibility indicators declines in regressions that include product market regulation (PMR) indicators as additional regressors, hinting at possible moderate omitted-variable bias in the regressions reported in Table 2. However, an important limitation concerning the OECD's PMR indicators is that they are only available for 1998, 2003, 2008, and 2013.

${ }^{15}$ Using a panel of firm-level data from Spanish manufacturers, Correa-López and Doménech (2017) find that better service regulation positively affects export volumes of large firms, through an input cost channel.
} 
panel regression results, Spain's 2010 and 2012 labor market reforms accounted for nearly one-tenth to above one-quarter of its total export growth rate from 2010 to 2013.

The outlook for Spanish exports is positive, but there is room for further improvement underpinned by good policies. Several recent developments suggest favorable prospects for export growth, including likely structural changes in geographic diversification and the number of regular exporters. The contribution of regained competitiveness to the success of exports should not be overlooked, and further upgrades in productivity growth and the functioning of labor markets, building on past reforms, are warranted. Exports could also benefit from enhancing competition in product markets. To improve export quality, relevant literature suggests an important role for policies aimed at strengthening human capital and institutions, including government efficiency and regulatory quality (see, e.g., Henn et al., 2017 and European Commission, 2018a). Additionally, upgrading the ability of workers to move across industries, regions, and skills would help ensure that the gains from trade are widely shared. This upgrade could be promoted through enhanced formal education, improved opportunities for vocational training and life-long learning, and targeted housing assistance (see IMF-WB-WTO, 2018). 


\section{REFERENCES}

Almunia, M., P. Antràs, D. Lopez-Rodriguez, and E. Morales, 2018, "Venting Out: Exports During a Domestic Slump," Mimeo.

Alvarez-López, M.E. and R. Myro, 2018, “Diversificación de Mercados y Crecimiento de la Exportación Española,” Mimeo.

Andrés, J., O. Arce, and C. Thomas, 2017, "Structural Reforms in a Debt Overhang," Journal of Monetary Economics, 88: 15-34.

Bank of Spain, 2016, "Competitive Adjustment and Recovery in the Spanish Economy," Annual Report 2015.

,2017, “Current Account Adjustment," Annual Report 2016.

, 2018, Economic Bulletin 1/2018.

Bassanini, A., L. Nunzieta, and D. Venn, 2009, “Job Protection Legislation and Productivity Growth in OECD Countries," Economic Policy, 24(58): 349-402.

Bayoumi, T., R. Harmsen, and J. Turunen, 2011, "Euro Area Export Performance and Competitiveness," IMF Working Paper 11/140, Washington: International Monetary Fund.

Bentolila, S. and G. Bertola, 1990, "Firing Costs and Labour Demand: How Bad is Eurosclerosis?" Review of Economic Studies, 57(3): 381-402.

Bluedorn, J. and H. Lin, 2017, "External Adjustment in Europe: Competitiveness, The Real Exchange Rate, and the Trade Balance," Euro Area Policies: Selected Issues, IMF Country Report No. 17/236, Washington: International Monetary Fund.

Bobeica, E., O. Tkacevs, and S. Christodoulopoulou, 2016, "The Role of Price and Cost Competitiveness for Intra- and Extra-Euro Area Trade of Euro Area Countries," European Central Bank Working Paper Series 1941.

Buck, T., 2017, “Spain: Boom to Bust and Back Again,” Financial Times, April 6.

Cacciatore, M., R. Duval, G. Fiori, and F. Ghironi, 2016, "Market Reforms in the Time of Imbalance," Journal of Economic Dynamics and Control, 72: 66-93.

Correa-López, M. and R. Doménech, 2017, "Service Regulations, Input Prices and Export Volumes: Evidence from a Panel of Manufacturing Firms," Banco de España Working Paper No. 1707, Madrid. 
Cuñat, A. and M. Melitz, 2012, "Volatility, Labor Market Flexibility, and the Pattern of Comparative Advantage," Journal of the European Economic Association, 10(2): $225-254$.

Dao, M., 2015, “Recent Labor Market Reforms: A Preliminary Assessment,” Spain: Selected Issues, IMF Country Report No. 15/233, Washington: International Monetary Fund.

De Lucio, J., R. Mínguez, A. Minondo, and F. Requena, 2017, “Los Márgenes del Crecimiento de las Exportaciones Españolas Antes y Después de la Gran Recesión," Estudios de Economía Aplicada, 35(1): 43-62.

De Lucio, J., R. Mínguez, A. Minondo, and F. Requena, 2018, “¿Se ha Producido un Milagro Exportador en España?," Mimeo.

Doménech, R., J.M. García, and C. Ulloa, forthcoming, "The Effects of Wage Flexibility on Activity and Employment in the Spanish Economy," Journal of Policy Modeling.

Duval, R. and D. Furceri, 2018, “The Effects of Labor and Product Market Reforms: The Role of Macroeconomic Conditions and Policies," IMF Economic Review, 66(1): 31-69, Washington: International Monetary Fund.

Duval, R., D. Furceri, B. Hu, J. Tovar Jalles, and H. Nguyen, 2018, “A Narrative Database of Major Labor and Product Market Reforms in Advanced Economies," IMF Working Paper 18/19, Washington: International Monetary Fund.

Eppinger, P., N. Meythaler, M. Sindlinger, and M. Smolka, 2018, „The Great Trade Collapse and the Spanish Export Miracle: Firm-level Evidence from the Crisis," The World Economy, 41: 457-493.

European Commission, 2018, European Semester Country Report Spain 2018. ,2018a, "The Determinants of Export Quality in the Euro Area," Quarterly Report of the Euro Area, Vol. 17, No. 1.

Garicano, L., C. Cruz, 2018, “El Milagro Exportador Español,” El País, May 25.

González Pandiella, A., 2015, “A Constant Market Share Analysis of Spanish Goods Exports,” OECD Economics Department Working Papers (2015)4.

Gonzalez Sanz, M.J. and C. Machuca, 2015, "The Internationalisation of Spanish SMEs: Main Developments and Their Determinants," Banco de España, Economic Bulletin, December.

Grinberg, F., 2017, “Assessing Spain's Competitiveness, ” Spain: Selected Issues, IMF Country Report No. 17/24, Washington: International Monetary Fund. 
Henn, C., C. Papageorgiou, J.M. Romero, and N. Spatafora, 2017, "Export Quality in Advanced and Developing Economies: Evidence from a New Data Set," World Bank Policy Research Working Paper 8196, Washington: World Bank Group.

International Monetary Fund, 2016, “Time for a Supply-Side Boost? Macroeconomic Effects of Labor and Product Market Reforms in Advanced Economies," World Economic Outlook (April 2016), Chapter 3, Washington. , 2018, “2018 External Sector Report-Technical Supplement,” Washington.

International Monetary Fund, World Bank, and World Trade Organization, 2018, "Reinvigorating Trade and Inclusive Growth."

Izquierdo, M., A. Lacuesta, and S. Puente, 2013, “The 2012 Labour Reform: An Initial Analysis of Some of its Effects on the Labour Market," Banco de España, Economic Bulletin, September.

Myro, R., 2015, “España en la Economía Global: Claves del Exito de las Exportaciones Españolas,” RBA Libros.

, 2018, "Crecimiento Económico con Equilibrio Exterior. Un Nuevo Escenario para la Economía Española,” EuropeG, Policy Brief No.13.

OECD, 2014, “The 2012 Labour Market Reform in Spain: A Preliminary Assessment. OECD Publishing."

Prades, E. and C. García, 2015, “Actualización de la Función de Exportaciones Españolas de Bienes," Banco de España, Boletín Económico, Abril.

Prades, E. and P. Villanueva, 2017, "Spain in the Global Value Chains," Banco de España, Economic Bulletin 3/2017, Analytical Articles.

Stothard, M., 2018, “Spain's Exporters Drive Robust Economic Recovery,” Financial Times, April 23.

The Economist, 2017, "Bullish Again: Spain's Reforms Point the Way for Southern Europe," June 15. 


\section{Appendix: Further Details and Results Related to the Cross-Country Panel Regressions}

The data for the cross-country panel regressions are taken from the IMF's WEO database, the OECD's Employment Protection Database, and the WEF's Global Competitiveness Report Database. The table below summarizes the sources and availability for the employment protection indicators reported in the paper. Given that the OECD indicators reflect employment protection regulations that were in force on January $1^{\text {st }}$ of a given year, they embody some degree of lagged reform effects. Other labor marketrelated indicators from OECD and the WEF-GCI databases were included in alternative regressions (not reported), but they did not produce statistically significant results.

\begin{tabular}{|l|c|c|}
\hline \multicolumn{1}{|c|}{ Employment Protection Indicators Included in the Reported Regressions } \\
\hline $\begin{array}{l}\text { Regulation of regular contracts (individual } \\
\text { dismissals) ("EPR_V1") }\end{array}$ & Years & Source \\
$\begin{array}{l}\text { Regulation of regular contracts (individual and } \\
\text { collective dismissals) ("EPRC_V2") }\end{array}$ & $1995-2013$ & $\begin{array}{c}\text { OECD - Employment } \\
\text { Protection database }\end{array}$ \\
$\begin{array}{l}\text { Regulation of temporary contracts ("EPT_V1") } \\
\text { Average length of notice period ("REG3" }\end{array}$ & $1985-2013$ & \\
simple average of 'REG3a', 'REG 3b', and 'REG3c') & $1985-2013$ & \\
\hline Hiring and firing practices ("Hiring/Firing") & $2006-2015$ & $\begin{array}{c}\text { World Economic Forum - } \\
\text { Global Competitiveness Index } \\
\text { Historical Dataset }\end{array}$ \\
\hline
\end{tabular}

The chart below illustrates the evolution of the employment protection indicators for Spain. Notably, most of them show improvements coinciding with the implementation of the labor market reforms of 2010 and 2012.

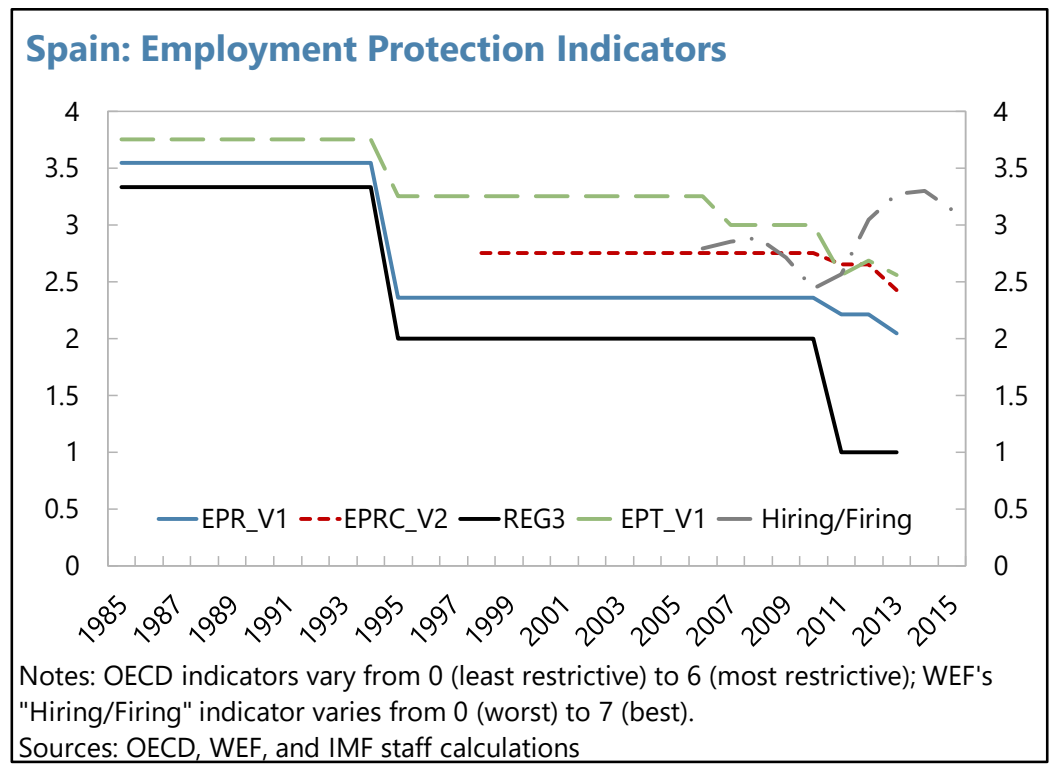

CInternational Monetary Fund. Not for Redistribution 
To gain observations in the regressions, the OECD indicators were extended until 2016, under the conservative assumption of no-changes in employment protection legislations since 2013. But the results are robust to estimating the regressions only until 2013.

In several robustness exercises, the key results were mostly unchanged. In addition to the exercises reported in the main text, the following experiments were considered: (i) dropping the lagged log change of the ULC-based REER as control, and adding instead either the lagged log change of the nominal effective exchange rate (NEER) or both the lagged and contemporaneous log change of the NEER; (ii) adding a lagged interaction term of the lowgrowth dummy with the labor market flexibility indicator; and (iii) controlling for product market reform indicators taken from Duval et al.'s (2018) database. In all these robustness experiments, the main baseline results were largely unchanged, though in some cases the magnitudes of the $\beta$ coefficients declined somewhat (in absolute value). However, in an exercise where all the labor market flexibility indicators were lagged one period, the coefficients on the key regressors of interest became statistically insignificant. Finally, in alternative regressions that included labor market regulation indicators from Duval et al.'s (2018) database, the estimated coefficient attached to their indicator on "employment protection legislation for regular workers" had the expected sign (i.e., implying that less stringent employment protection has positive effects on exports) but was statistically insignificant. 